\title{
PROSES KEPERAWATAN SEBAGAI TAHAP DALAM MEMBERI ASUHAN KEPERAWATAN PADA PASIEN
}

Pebi Septrian Sari

febi.septrian03@gmail.com

\section{LATAR BELAKANG}

Rumah sakit merupakan salah satu sarana pelayanan kesehatan bagi klien sehat atau sakit yang membutuhkan bantuan pelayanan dari tim kesehatan termasuk perawat. Tenaga perawat yang merupakan "The caring profession" mempunyai kedudukan penting dalam menghasilkan kualitas pelayanan kesehatan di rumah sakit, karena pelayanan yang diberikannya berdasarkan pendekatan bio-psiko-sosial-spiritual merupakan pelayanan yang dilaksanakan selama 24 jam dan berkesinambungan merupakan kelebihan tersendiri dibanding pelayanan lainnya. Perawat merupakan salah satu tenaga medis di rumah sakit yang memberikan pelayanan untuk menunjang kesembuhan pasien, oleh sebab itu peran perawat di rumah sakit sangatlah dibutuhkan.

Tim keperawatan memberikan pelayanan asuhan keperawatan kepada klien menggunakan metode proses keperawatan dengan mengacu pada kode etik dan standar praktek yang ditetapkan. Dimaksudkan agar pelayanan keperawatan yang diberikan senantiasa aman dan dapat memenuhi kebutuhan serta harapan klien. Perawat, dimana saja ia bertugas,menghadapi klien dengan segala macam kasus, dan melayani klien pada semua tingkat usia juga harus menggunakan proses keperawatan. Perawat diharapkan memahami tentang konsep proses keperawatan dan mampu menerapkan serta menyusunannya dalam sebuah dokumen status kesehatan klien.

Ilmu keperawatan didasarkan pada suatu teori yang sangat luas.Menurut Lyer dkk (1996) proses keperawatan adalah metode dimana suatu konsep diterapkan dalam praktik keperawatan. Hal ini dapat disebut sebagai suatu pendekatan untuk memecahkan masalah (problem solving) yang memerlukakn ilmu, teknik, dan keterampilan interpersonel yang bertujuan untuk memenuhi kebutuhan klien, keluarga, dan masyarakat. Proses keperawatan terdiri atas lima tahap yang berurutan dan salng berhubungan, yaitu pengkajian, diagnosis, perencanaan, implementasi, dan evaluasi. Tahap-tahap tersebut berintegrasi terhadap fungsi intelektual problem-solving dalam mendefinisikan suatu asuhan keperawatan (Nursalam,2008). 
Asuhan keperawatan adalah suatu pendekatan untuk pemecahan masalah yang memampukan perawat untuk mengatur dan memberikan asuhan keperawatan. Asuhan ini diberikan melalui metode yang disebut proses keperawatan. Proses keperawatan yang didasari teori Orlando Deliberative Nursing Process ini menyatakan bahwa tindakan atau perilaku yang ditunjukkan perawat merupakan hasil pertimbangan berdasarkan kebutuhan pasien. Hal tersebut berarti bahwa perawat profesional melakukan eksplorasi kebutuhan dan masalah atau gangguan kebutuhan yang terjadi pada pasien dengan menggunakan persepsi, proses berpikir kritis, penalaran klinis, dan atau perasaan perawat yang berhubungan dengan kebutuhan dasar pasien.

Mutu asuhan keperawatan sangat dipengaruhi oleh kualitas pelayanan kesehatan dan bahkan sering menjadi salah satu faktor penentu citra institusi pelayanan di mata masyarakat. Untuk menilai kualitas pelayanan keperawatan diperlukan adanya standar praktik keperawatan yang merupakan pedoman bagi perawat dalam melaksanakan asuhan keperawatan yang diwujudkan dalam bentuk proses keperawatan baik dari pengkajian sampai evaluasi (Nursalam,2008). Proses keperawatan juga bertujuan untuk menyelesikan suatu maslah secara sistematis dan logis sehingga pelayanan yang diberikan optimal dan berkualitas. Jika proses keperawatan dapat tercapai maka setiap langkah harus memiliki suatu tujuan yang jelas dan spesifik beserta indikator-indikatornya. Sedangkan tujuan dari asuhan keperawatan dapat dicapai apabila semua anggota tim kesehatan bekerjasama dalam memecahkan masalah klien begitu dengan duungan keluarga klien.

\section{METODE}

Metode yang digunakan pada penulisan ini menggunakan metode literature review atau studi literatur dengan cara menganalisis dan melakukan eksplorasi terhadap bahan kajian yang berfokus pada pokok pembahasan yang berhubungan dengan Proses keperawatan sebagai tahap dalam memberikan asuhan keperawatan. Penulisan ini menggunakan sumber referensi berupa jurnal, artikel, textbook, e-book yang relevan dan terpercaya. Jurnal yang dipakai merupakan jurnal yang diterbitkan dalam 10 tahun terakhir.

\section{HASIL}

Hasil dari melakukan proses pencarian dan pengkajian literature terhadap sumber, telah didapati bahwa penerapan proses keperawatan dapat mempermudah pemberian asuhan keperawatan yang memudahkan penyelesaian masalah yang baik. Dengan proses keperawatan 
maka telah terarah pemberian asuhan keperawatan yang memperhatikan masalah yang di alami klien dan penyelesaian masalah klien dan kemudian dapat meningkatkan wawasan yang membangun pemberian asuhan keperwatan selanjutnya.

Proses keperawatan ini juga merupakan pendekatan ilmiah,terdiri dari lima tahap yaiu, pengkajian, diagnosa, perencanaan, implementasi dan evaluasi. Diagnosa keperawatan memberikan dasar-dasar pemilihan intervensi untuk mencapai hasilyang menjadi tanggung gugat perawat. Didalam diagnose keperawatan perumusan harus jelas singkat padat dan tepat dari respons klien terhadap situasi atau keadaan yang sedang dihadapi,dan memberikan asuhan keperawatan yang tepat.

\section{PEMBAHASAN}

Perawat melakukan perawatan berdasarkan respon manusia terhadap masalah kesehatan dan atau proses kehidupan. Perawat menangani respon terhadap gangguan kesehatan atau proses kehidupan antar-individu, keluarga, kelompok, dan masyarakat. Proses keperawatan adalah suatu metode yang sistematis dan terorganisasi dalam pemberian asuhan keperawatan, yang difokuskan pada reaksi dan respons unik individu pada suatu kelompok atau perorangan terhadap gangguan kesehatan yang dialami, baik actual maupun potensial (Deswani, 2009). Proses keperawatan dilakukan dengan pendekatan problem solving yang memerlukan ilmu, teknik, dan keterampilan interpersonal untuk memenuhi kebutuhan klien/keluarganya.

Proses keperawatan tersebut memiliki lima fase atau tahap yang meliputi pengkajian, diagnosis, perencanaan, implementasi dan evaluasi. Proses keperawatan memiliki tujuan adalah untuk mempraktikkan metode pemecahan masalah dalam praktik keperawatan, untuk menggunakan standar untuk praktik keperawatan, untuk memperoleh metoda yang baku dan sesuai, rational dan sistematis dalam memberikan asuhan keperawatan pada pasien, serta untuk memperoleh metode yang dapat digunakan dalam segala situasi. Tujuan umum dari proses keperawatan adalah peningkatan kualitas asuhan keperawatan. Adanya proses keperawatan akan menciptakan pelayanan asuhan keperawatan yang berkualitas dengan indikator teratasinya semua masalah yang terkait dengan kebutuhan dasar manusianya klien.

Asuhan professional dituntut untuk dapat melaksanakan proses keperawatan dengan tepat dan benar. Pemahaman perawat terhadap proses keperawatan sangat penting, karena menjadi satu hal utama dalam melaksanakan asuhan keperawatan. Proses keperawatan akan 
membedakan asuhan keperawatan professional dengan asuhan keperawatan tradisional. Kemampuan untuk menerapkan proses keperawatan tidak dapat ditawar-tawat lagi

Tahapan Proses Keperawatan :

\section{Pegkajian}

Pengkajian merupakan upaya mengumpulkan data secara lengkap dan sistematis untuk dikaji dan dianalisis sehingga masalah kesehatan dan keperawatan yang dihadapi pasien baik fisik, mental, sosial, maupun spiritual dapat ditentukan. Pada tahap ini meliputi tiga kegiatan, yaitu Pengumpulan data, Analisa data, dan Penentuan masalah kesehatan serta keperawatan.

\section{Diagnosa keperawatan}

Diagnosa keperawatan adalah suatu pernyataan yang menjelaskan respon manusia (status kesehatan atau risiko perubahan pola) dari individu atau kelompok dimana perawat secara akuntabilitas dapat mengidentifikasi dan memberikan intervensi secara pasti untuk menjaga status kesehatan, menurunkan, membatasi, mencegah, dan merubah. Perumusan diagnosa keperawatan, yaitu actual, risiko, kemungkinan, wellness, dan syndrom.

\section{Perencanaan}

Perencanaan keperawatan merupakan pedoman tertulis untuk perawatan klien. Rencana keperawatan terorganisasi sehingga setiap perawat dapat dengan cepat mengidentifikasi tindakan perawatan yang diberikan. Rencana asuhan keprawatan yang dirumuskan dengan tepat memfasilitasi kontinuitas asuhan keperawatan dari satu perawat ke perawat lainnya. Sebagai hasil, semua perawat mempunyai kesempatan untuk memberikan asuhan yang berkualitas tinggi dan konsisten.

\section{Implementasi}

Implementasi merupakan inisiatif dari rencana tindakan untuk mencapai tujuan yang spesifik. Tahap pelaksanaan dimulai setelah rencana tindakan disusun dan ditujukan pada nursing orders untuk membantu klien mencapai tujuan yang diharapkan. Oleh karena itu, renacana tindakan yang spesifik dilaksanakan untuk memodifikasi faktor-faktor yang mempengaruhi masalah kesehatan klien. Adapun tahap dalam tindakan keperawatan, yaitu persiapan, intervensi, dan dokumentasi.

5. Evaluasi 
Perencaan evaluasi memuat kriteria keberhasilan proses dan keberhasilan tindakan keperawatan. Keberhasilan proses dapat dilihat dengan jalan membandingkan antara proses dengan pedoman/rencana proses tersebut. Sedangkan keberhasilan tindakan dapat dilihat dengan membandingkan antara tingkat kemandirian pasien dalam kehidupan sehati-hari dan tingkat kemajuan kesehatan pasien dengan tujuan yang telah dirumuskan sebelumnya.

Sasaran evaluasi, yaitu proses asuhan keperawatan berdasarkan kriteria/rencana yang telah disusun, dan Hasil tindakan keperawatan,berdasarkan kriteria keberhasilan yang telah dirumuskan dalam rencana evaluasi.

Dalam proses keperawatan juga terdapat sifat-sifat yang akan membuat perawat dapat dengan mudah memberikan asuhan keperawatan. Setiadi (2012) menjelaskan tentang sifat proses keperawatan, yaitu :

1. Dinamis, Setiap proses keperawatan dapat diperbaharui/dimodifikasi seorang klien, apabila situasi dan kondisi pasien mengalami perubahan kearah yang baik atau tidak.

2. Siklik, Proses keperawatan berjalan secara siklik atau berulang dari pengkajian sampai dengan evaluasi, demikian seterusnya apabila diperlukanpen pengkajian ulang (re-assesment), sampai masalah klien teratasi atau klien dapat mandiri mandiri memenuhi kebutuhan kesehatan atau keperawatannya.

3. Interdependent/saling ketergantungan, Setiap tahap dari proses keperawatan mempunyai relevansi yang sangat erat dan saling berhubungan antara diagnosa keperawatan dan pengkajian atau rencana tindakan keperawatan dan diagnosa keperawatan. Sehingga kekurangan disalah satu tahap akan mempengaruhi tahap-tahap berikutnya.

4. Fleksibel, Proses keperawatan bersifat luwes, tidak kaku sehingga pendekatan yang digunakan dapat berubah atau dimodifikasi sesuai dengan situasi, keadaan dan kebutuhan klien akan perawatan kesehatan.

Langkah-langkah pada proses keperawatan adalah mengumpulkan informasi, menentukan diagnosa keperawatan actual dan potensial, mengidentifikasi hasil yang dapat diukur dan menggambarkan respon pasien, mengembangkan intervensi individu yang bertujuan mencapai hasil, mengevaluasi kemajuan pencapaian tujuan, menilai rencana keperawatan didasarkan pada penggunaan proses keperawatan. Dalam mencapai kuaitas asuhan keperawatan yang baik, perawat harus mampu melakukan proses keperawatan yang baik dan benar. Dimana proses 
keperawatan merupakan sumbangan yang diberikan perawat melalui pelaksanaan proses keperawatan. Proses keperawatan merupakan kerangka pikir yang digunakan oleh seorang perawat untuk melaksanakan fungsi dan tanggung jawabnya secara mandiri.

\section{PENUTUP}

Proses keperawatan adalah suatu cara atau metode yang sistematis dalam memberikan asuhan keperawatan yang dilakukan oleh perawat dan bekerjasama dengan pasien (induvidu, keluarga, masyarakat) yang bertujuan untuk mengidentifikasi masalah keperawatan dengan melakukan pengkajian, menentukan diagnosa, merencanakan tindakan yang akan dilakukan, melaksanakan tindakan serta mengevaluasi hasil asuhan keperawatan yang telah diberikan dengan berfokus pada pasien, berorientasi pada tujuan yang telah ditetapkan bersama.

Untuk menjalankan semua tahapan ini, seorang perawat harus memiliki keterampilan dan pengetahuan yang cukup agar bisa mengatasi dan menghadapi masalah masakah klien dan dapat mengambil keputusan yang tepat dan benar serta dapat memberikan kebebasan kepada klien untuk mendapatkan pelayanan yang cukup sesuai dengan kebutuhannya, sehingga dapat dirasakan manfaat baik perawat ataupun klien. 


\section{DAFTAR PUSTAKA :}

Achmadi, L,D,I., Pondang, L \& Babakal, A. (2015). Gambaran Tingkat Pengetahuan Perawat Dalam Penerapan Standar Asuhan Keperawatan Di Ruangan Rawat Inap Interna RSUD Datoe Bhinangkang. E-Journal Keperawatan. Vol. 3(3).

Deswani. (2009). Proses Keperawatan dan Berpikir Kritis. Jakarta: Salemba Medika.

Mohamad, Kasim,M,A (2016). Peningkatan Kualitas Pelayanan Dan Pendokumentasian Asuhan Keperawatan Dengan Metode Tim. NurseLine Journal, 1(1), 62-72.

Nursalam. (2008). Proses dan Dokumentasi Keperawatan. Jakarta: Salemba Medika.

Setiadi. (2012). Konsep \& Penulisan Dokumentasi Asuhan Keperawatan;Teori dan Praktik. Yogyakarta : Graha Ilmu

Supratti, \& Ashriady. (2016). Pendokumentasian Standar Asuhan Keperawatan di Rumah Sakit Umum Daerah Mamuju, Indonesia. Jurnal Kesehatan Manarang. Vol 2. 44-51.

Susanto, Rachmat. (2010). Penerapan Standar Proses Keperawatan di Puskesmas Rawat Inap Cilacap. Jurnal Keperawatan Soedirman, 5(2), 80-84

Simamora, R. H. (2019). Development of Guidelines for Applying appropriate Patient Identification to Achieve Patient Safety Goal INC2019 12th International Nursing Conference. 2019.10455 - 455 (1 pages) UCI(KEPA) : I410-ECN-0101-2019-512-001224337

Simamora. R. H. (2008) The correlation of ward chief's giving direction and command and the performance of on-duty nurses at Jember dr. Subandi general hospital inpatient wards. jurnal Administrasi dan Kebijakan Kesehatan, (https://fkm.unair.ac.id/jurnal-administr)

Terik,M., Sumarauw,H., \& Onseng, L,S. (2015). Hubungan Kinerja Perawat Pelaksana Dengan Penerapan Proses Keperawatan Di Irina C Blu RSUP Dr.R.D. Kandou Manado. JUIPERDO. Vol.4(1). 55-56

Yanti, I,R \& Warsito,E, B. (2013). Hubungan Karakteristik Perawat, Motivasi, dan Supervisi Dengan Kualitas Dokumentasi Proses Asuhan Keperawatan. Jurnal Managemen Keperawatn. Vol 1(2). 107-114. 
Yeni, Fitra. (2014). Pengaruh Pelatihan Proses Keperawatan terhadap Dokumentasi Asuhan Keperawatan di Puskesmas Kabupaten Agam Propinsi Sumatera Barat. Jurnal Keperawatan, 10(1), 20-27. 